\title{
Model Problem Based Learning untuk Meningkatkan Prestasi Belajar Bahasa Indonesia Materi “Menyampaikan Pidato Persuasif” Kelas IX-F Madrasah Tsanawiyah Negeri 2 Kudus pada Semester Gasal Tahun Pelajaran 2019/2020
}

\author{
Wiwik Indarto \\ Madrasah Tsanawiyah Negeri 2 Kudus \\ Email Korespondesi: cintaindarto@gmail.com
}

\begin{abstract}
ABSTRAK: Pembelajaran Bahasa Indonesia dapat dikatakan menjadi asing di kampung halaman sendiri. Hal ini mengingat ada kecenderungan peserta didik yang lebih bangga menggunakan bahasa Asing dibandingkan dengan bahasa sendiri. Penelitian ini dimaksudkan untuk mendeskripsikan Model Problem Based Learning (PBL) dalam rangka meningkatkan prestasi belajar Bahasa Indonesia siswa kelas IX-F Madrasah Tsanawiyah Negeri 2 Kudus pada Semester Gasal Tahun Pelajaran 2019/2020. Subjek penelitian tindakan kelas ini adalah siswa kelas IX-F. Variabel penelitian ini terdiri dari variabel siswa dan variabel guru. Penelitian dilakukan dengan dua siklus dan masing-masing siklus terdiri atas empat tahapan, yakni: perencanaan, pelaksanaan, observasi dan refleksi. Indikator keberhasilan ditetapkan bila minimal terdapat 75\% siswa mencapai ketuntasan belajar setelah diterapkan Model Problem Based Learning ( $P B L)$. Hasil penelitian menunjukkan bahwa ada peningkatan prestasi belajar siswa kelas IX-F Peningkatan itu ditunjukkan dengan: (1) rata-rata prestasi belajar siswa pada siklus I adalah 7,08 dan pada siklu siklus II adalah 8,68; (2) ketuntasan belajar siswa pada siklus I siswa 15 siswa atau 50,00\% dan yang tidak tuntas sebanyak 15 siswa atau 50,00\%; serta (3) ketuntasan belajar klasikal pada siklus I adalah $50,00 \%$ dan pada siklus II mencapai $100,00 \%$. Ini berarti uji kompetensi/hasil evaluasi siklus II lebih baik dibandingkan siklus I, dan juga sudah mencapai indikator ketuntasan. Terdapat peningkatan aktivitas siswa selama proses pembelajaran secara individu maupun kelompok. Respon siswa mencapai $82,83 \%$ dengan kategori tinggi.
\end{abstract}

Kata kunci: Bahasa Indonesia, PBL, Penelitian Tindakan.

ABSTRACT: Learning Bahasa can be said to be foreign in your own hometown. This is because there is a tendency for students to be more proud to use foreign languages than their own languages. This research is intended to describe the Problem Based Learning (PBL) Model in order to improve the Indonesian language learning achievement of class IX-F students at Madrasah Tsanawiyah Negeri 2 Kudus in the Odd Semester of the 2019/2020 Academic Year. The subjects of this classroom action research were students of class IX-F. The research variables consisted of student variables and teacher variables. The research was conducted in two cycles and each cycle consisted of four stages, namely: planning, implementing, observing and reflecting. Success indicators are determined when at least $75 \%$ of students achieve learning completeness after the implementation of Problem Based Learning (PBL) Model. The results showed that there was an increase in student achievement in class $I X-F$. The increase was indicated by: (1) the average student achievement in cycle I was 7.08 and cycle II was 8.68; (2) completeness of student learning in the first cycle of 15 students or $50.00 \%$ and 15 students or $50.00 \%$ who did not complete; and (3) completeness of classical learning in the first cycle was $50.00 \%$ and in the second cycle it reached $100.00 \%$. This means that the competency test / evaluation result of cycle II is better than cycle I, and has also reached the completeness indicator. There is an increase in student activity during the learning process individually or in groups. Student response reached $82.83 \%$ in the high category.

Keywords: Action Research, Bahasa Indonesia, PBL 


\section{PENDAHULUAN}

Dalam Undang-Undang Dasar RI 1945 Bab XV tentang (Bendera, Bahasa, dan Lambang Negara, serta Lagu Kebangsaan) pasal 36 disebutkan bahwa sebagai bahasa negara, bahasa Indonesia berfungsi sebagai bahasa resmi kenegaraan, bahasa pengantar resmi di lembaga - lembaga pendidikan, bahasa resmi dalam perhubungan pada tingkat nasional untuk kepentingan perencanaan dan pelaksanaan pembangunan serta pemerintah, dan bahasa resmi dalam pengembangan kebudayaan dan pemanfaatan ilmu pengetahuan serta teknologi modern (Nuh, 2014).

Pembelajaran bahasa Indonesia dapat dikatakan menjadi asing di kampung halaman sendiri. $\mathrm{Hal}$ ini mengingat ada kecenderungan peserta didik yang lebih bangga menggunakan bahasa Asing dibandingkan dengan bahasa sendiri. Sikap seperti ini tercermin dalam kehidupan sehari - hari baik dalam situasi formal maupun nonformal. Misalnya ketika seseorang lebih fasih menyebut kata website dibandingkan dengan kata laman yang menjadi padanan dari kata tersebut. Hal sejenis terjadi pada pengunaan istilah lain seperti handphone yang lebih familiar dibandingkan telefon genggam, email dengan pos - el (pos elektronik), dan lain sebagainya (Pupuh, 2018; Hikmat \& Solihati, 2013).

Selain sikap berbahasa diatas, sikap lain yang tercermin adalah bagaimana seseorang lebih bangga menggunakan pengaturan telefon genggamnya atau komputernya dengan bahasa Inggris dibandingkan dengan bahasa Indonesia. hal ini merupakan fenomena ironis. Dalam pembelajaran bahasa Indonesia, kegiatan berbahasa diarahkan pada berbahasa secara formal yang digunakan dalam pembuatan naskah pidato, makalah, berita, cerita, surat, laporan, maupun proposal (Karnisius, Hikmat, \& Sholihat, 2013).

\begin{tabular}{lll}
\multicolumn{1}{c}{ Dalam } & kaitannya & dengan \\
penerapan & beragam & strategi \\
pembelajaran, & pembelajaran & bahasa
\end{tabular}
Indonesia mengalami berbagai masalah. Berdasarkan karakteristik siswa, beberapa problematika adalah kematangan mental dan kecakapan intelektual siswa kurang merata, kecakapan psikomotorik dan keterampilan berbahasa siswa masih rendah, dan strategi pembelajaran bahasa yang digunakan masih kurang sesuai dengan umur siswa.

Berdasarkan strategi pembelajaran, beberapa masalah yang muncul berupa: (1) masih banyak guru belum mampu memilih dan menggunakan strategi pembelajaran bahasa Indonesia sesuai dengan karakteristik siswa, tipe belajar siswa, bahan ajar, dan alokasi waktu. Berdasarkan sarana dan prasarana, beberapa masalah yang muncul adalah sarana/prasarana kurang memadai dan guru tidak mampu menggunakan sarana/prasarana secara optimal (Depdiknas, 2017). Salah satu model pembelajaran yang perlu dikembangkan dan diterapkan pada proses pembelajaran Bahasa Indonesia di dalam kelas adalah model Problem Based Learning (PBL) (Gorghiu et al., 2015).

Pembelajaran Berbasis Masalah (Problem Based Learning/PBL) merupakan suatu pendekatan pembelajaran yang menggunakan masalah dunia nyata sebagai suatu konteks bagi siswa untuk belajar tentang berpikir kritis dan keterampilan pemecahan masalah serta untuk memperoleh pengetahuan dan konsep yang esensi dari materi pelajaran (Hintz, 
2005; Moffit, 2017). Pembelajaran Berbasis Masalah merupakan salah satu pendekatan pembelajaran yang digunakan untuk merangsang berpikir tingkat tinggi siswa dalam situasi yang berorientasi pada masalah dunia nyata, termasuk di dalamnya belajar bagaimana belajar (Ibrahim \& M, 2000:2). Kejadiankejadian yang harus muncul dalam implementasi PBL, adalah: (1) keterlibatan (engagement): mempersiapkan siswa untuk berperan sebagai pemecah masalah dengan bekerja sama; (2) inquiry dan ivestigasi: mengeksplorasi dan mendistribusikan informasi; (3) performansi: menyajikan temuan; (4) tanya jawab (debriefing): menguji keakuratan dari solusi; dan (5) refleksi terhdap pemecahan masalah (Howey (2001:69).

Pembelajaran berbasis masalah merupakan penggunaan berbagai macam kecerdasan yang diperlukan untuk melakukan konfrontasi terhadap tantangan dunia nyata, kemampuan untuk menghadapi segala sesuatu yang baru dan kompleksitas yang ada (Tan, 2003). Problem Based Learning (PBL) merupakan inovasi dalam pembelajaran, karena dalam $P B L$ kemampuan berpikir siswa betul-betul dioptimalisasikan melalui proses kerja kelompok atau tim yang sistematis, sehingga siswa dapat memberdayakan, mengasah, menguji, dan mengembangkan kemampuan berpikirnya secara berkesinambungan. (Major \& Mulvihill, 2018).

Konsep dasar pembelajaran berbasis masalah adalah sebuah pendekatan pembelajaran yang menyajikan masalah kontekstual sehingga merangsang peserta didik untuk belajar. Dalam kelas yang menerapkan pembelajaran berbasis masalah, peserta didik bekerja dalam tim untuk memecahkan masalah dunia nyata (real world). PBL merupakan suatu metode pembelajaran yang menantang peserta didik untuk "belajar bagaimana belajar," bekerja secara berkelompok untuk mencari solusi dari permasalahan dunia nyata (Krishnan et al., 2011).

Pembelajaran Berbasis Masalah adalah inovasi yang paling signifikan. Kurikulum PBL membantu untuk meningkatkan perkembangan keterampilan belajar sepanjang hayat dalam pola pikir yang terbuka, reflektif, kritis, dan belajar aktif. Kurikulum PBL memfasilitasi keberhasilan memecahkan masalah, komunikasi, kerja kelompok dan keterampilan interpersonal dengan lebih baik dibanding pendekatan yang lain (Watson, 1996).

Model pembelajaran berbasis masalah dilakukan dengan adanya pemberian rangsangan berupa masalahmasalah yang kemudian dilakukan pemecahan masalah oleh peserta didik yang diharapkan dapat menambah keterampilan peserta didik dalam pencapaian materi pembelajaran. Studi kasus pembelajaran berbasis masalah meliputi: (1) penyajian masalah; (2) menggerakkan inquiry; (3) langkahlangkah PBL, yaitu analisis inisial, mengangkat isu-isu belajar; iterasi kemandirian dan kolaboasi pemecahan masalah. Integrasi pengetahuan baru, penyajian solusi dan evaluasi (Rosidah, 2018; Hintz, 2005; Depdiknas, 2017:12).

PBL digunakan berdasarkan tujuan yang akan dicapai yang berkaitan dengan; (1) penguasaan isi pengetahuan yang bersifat multi disipliner; (2) penguasaan keterampilan proses dan disiplin heuristic; (3) belajar keterampilan pemecahan masalah; (4) belajar keterampilan kolabotatif; dan (5) belajar keterampilan kehidupan yang lebih luas. 
PBL melibatkan siswa dalam penyelidikan pilihan sendiri yang memungkinkan mereka menginterpretasikan dan menjelaskan fenomena dunia nyata dan membangun pemahamannya tentang fenomena itu. Menurut Birch (1986:3) Langkah-langkah yang akan dilalui oleh siswa dalam sebuah proses PBL adalah (1) menemukan masalah; (2) mendefinisikan masalah; (3) mengumpulkan fakta dengan menggunakan KND; (4) pembuatan hipotesis; (5) penelitian; (6) rephrasing masalah; (7) menyuguhkan alternatif; (8) mengusulkan solusi.

Kenyataan yang ada di Madrasah Tsanawiyah Negeri 2 Kudus, menunjukkan bahwa prestasi belajar siswa cenderung statis dan stagnan dan bahkan mengalami penurunan. Masalah ini terjadi karena tidak adanya moitvasi belajar siwa, sebagai akibat penerapan model pembelajaran yang kurang tepat, monoton, dan tidak ada variasi dalam proses pembelajaran, sehingga menimbulkan kesan kejenuhan dan rasa bosan pada diri siswa. Sebagai akibatnya prestasi belajar siswa tidak mengalami peningkatan, khusunya prestasi belajar Bahasa Indonesia siswa kelas IX-F Madrasah Tsanawiyah Negeri 2 Kudus. Sebagai solusinya peneliti (penulis) ingin menerapkan Model Problem Based Learning (PBL) dalam prose pembelajaran.

Berdasarkan hal tersebut, maka perlu kiranya ada sebuah bahan kajian yang mendalam tentang apa dan bagaimana Model Problem Based Learning (PBL) ini untuk selanjutnya diterapkan dalam sebuah proses pembelajaran, sehingga dapat memberi masukan, khususnya kepada para guru tentang Model Problem Based Learning $(P B L)$, yang menurut (Tan, 2003) merupakan pendekatan pembelajaran yang relevan dengan tuntutan abad ke 21 dan umumnya kepada para ahli dan praktisi pendidikan yang memusatkan perhatiannya pada pengembagnan dan inovasi sistem pembelajaran. Penelitian ini bertujuan untuk mengetahui apakah penerapan model Problem Based Learning (PBL) dapat meningkatkan prestasi belajar dan keaktifan siswa kelas IX-F Madrasah Tsanawiyah Negeri 2 Kudus semester gasal tahun pelajaran 2019/2020.

\section{METODOLOGI PENELITIAN}

Metode penelitian ini adalah dalam bentuk penelitian tindakan kelas. Penelitian dilaksanakan dalam dua siklus (siklus I dan siklus II). Masing-masing siklus terdiri dari perencanaan, pelaksanaan, pengamatan dan refleksi. Hasil penelitian dititik-beratkan pada kemampuan siswa dalam mengerjakan soal evaluasi pembelajaran sehingga prestasi belajar dan ketuntasan belajar dapat tercapai. Alur dalam penelitian tindakan kelas ini terdiri atas 4 rangkaian kegiatan yang dilakukan dalam siklus berulang. Empat kegiatan utama yang ada pada setiap siklus yaitu perencanaan, tindakan, pengamatan dan refleksi. Sesuai dengan gagasan peneliti, maka penelitian tindakan kelas ini dirancang untuk dilaksanakan dalam dua siklus sehingga mencapai hasil yang diharapkan (Diyas Puspandari, 2010).

Penelitian tindakan kelas ini dilakukan dalam waktu 3 (tiga) bulan, mulai bulan September sampai dengan bulan Nopember pada semester gasal tahun pelajaran 2019/2020, mulai dari observasi awal, perencanaan, pelaksanaan siklus I, pelaksanaan siklus II, dan penyusunan laporan (Khasinah, 2013). 
Subjek penelitian tindakan kelas ini adalah siswa Kelas IX-F Madrasah Tsanawiyah Negeri 2 Kudus semester gasal tahun pelajaran 2019/2020. Sumber data penelitian adalah siswa, peneliti/guru (peneliti sendiri). Jenis data dalam penelitian ini adalah data kualitatif dan data kuantitatif. Data kualitatif berupa hasil pengamatan aktifitas Peneliti/guru, melalui lembar observasi Peneliti/guru dan keaktifan siswa lewat lembar observasi siswa. Data kuantitatif berupa hasil pengamatan tentang kemampuan kognitif siswa dari hasil evaluasi.

Teknik pengambilan data dilakukan dengan cara angket, observasi, dan tes (Sugiyono, 2017). Angket berupa tanggapan siswa terhadap penerapan model pembelajaran, diperoleh dari angket siswa. Observasi berupa hasil observasi terhadap pelaksanaan penelitian digunakan untuk mengetahui aktivitas siswa selama mengikuti proses pembelajaran, diperoleh dari lembar observasi siswa. Tes berupa data nilai prestasi belajar setelah dilakukan pembelajaran dengan model pembelajaran, adapun tes berupa soal uraian. Tahap pengambilan data terdiri dari: (1)

Data prestasi belajar siswa diambil dari hasil evaluasi, (2) Data tentang proses pembelajaran pada saat dilaksanakannya tindakan diambil dengan lembar observasi siswa, (3) Data tentang refleksi serta perubahan-perubahan yang terjadi di kelas diambil dari hasil pengamatan dan hasil evaluasi, (4) Data kemampuan dan ketrampilan Peneliti/guru dalam melaksanakan kegiatan belajar mengajar dengan model pembelajaran yang diterapkan, dengan menggunakan lembar observasi guru/peneliti.
Analisis data mengggunakan teknik analisis kualitatif untuk mengetahui tiga variable data yaitu aktivitas siswa, prestasi belajar, dan minat siswa (Yin, 2016; Miles \& Huberman, 1994). Data aktivitas siswa berupa seberapa besar keaktivan siswa dalam mengikuti proses pembelajaran, maka analisis ini dilakukan pada instrumen hasil evaluasi dengan menggunakan teknik deskriptif melalui prosentase keaktifan siswa dengan perhitungan prosentase sebagai berikut:

$$
\begin{aligned}
& \text { Prosentase }(\%)=\frac{n}{N} \times 100 \% \\
& \text { Keterangan: } \\
& \mathrm{n} \quad=\text { Skor yang diperoleh tiap } \\
& \text { siswa } \\
& \mathrm{N} \quad=\text { Jumlah seluruh skor }
\end{aligned}
$$

Data mengenai prestasi belajar diambil dari kemampuan kognitif siswa dalam memecahkan masalah dianalisis dengan cara menghitung rata-rata nilai ketuntasan belajar secara klasikal dengan menggunakan rumus:

$$
\bar{X}=\frac{\Sigma \mathrm{X}}{N}
$$

$$
\begin{aligned}
& \text { Keterangan: } \\
& \bar{X} \quad=\text { Nilai rata-rata } \\
& \Sigma X \quad \text { = Jumlah seluruh nilai } \\
& \mathrm{N} \quad=\text { Jumlah siswa }
\end{aligned}
$$

Data minat siswa berguna untuk mengetahui tanggapan siswa dalam pembelajaran melalui model Problem Based Learning (PBL dengan kriteria penilaian jawaban untuk angket refleksi siswa terhadap pembelajaran.

Indikator keberhasilan untuk mengetahui meningkatnya hasil belajar siswa pada kemampuan kognitifnya (prestasi belajar) dengan menerapkan model Problem Based Learning (PBL), terdiri dari: (1) kemampuan siswa dalam 
menjawab soal evaluasi materi pembelajaran dapat meningkat dengan nilai di atas 7,5 mencapai sekurangkurangnya $80 \%$ dari jumlah siswa, (2) keaktivan siswa dalam proses pembelajaran dapat meningkat dengan skor antara $60 \%-75 \%$ mencapai keaktifan sedang, (3) keaktivan/kinerja Peneliti/guru dalam melaksanakan pembelajaran di dalam kelas yang dilihat dari lembar observasi aktifitas Peneliti/guru makin meningkat.

Hipotesis penelitian penelitian tindakan ini dapat dirumuskan sebagai berikut: (1) Ada pengingkatan prestasi belajar Bahasa Indonesia siswa kelas IX-F Madrasah Tsanawiyah Negeri 2 Kudus pada semester gasal tahun pelajaran 2019/2020 setelah penerapan Model Problem Based Learning (PBL); (2) Ada peningkatan keaktifan siswa kelas IX-F Madrasah Tsanawiyah Negeri 2 Kudus pada semester gasal tahun pelajaran 2019/2020 setelah penerapan Model Problem Based Learning (PBL).

\section{HASIL PENELITIAN DAN PEMBAHASAN}

\section{Hasil Penelitian}

Pembahasan dalam penelitian ini menggunakan teori Moffit (2017:12) bahwa PBL mengajak siswa untuk belajar tentang berpikir kritis dan keterampilan pemecahan masalah. Selain itu teori studi kasus pembelajaran berbasis masalah oleh Rosidah (2018) dan Hintz (2005) yang meliputi langkah-langkah: (1) penyajian masalah; (2) menggerakkan inquiry; (3) langkah-langkah PBL (yaitu analisis inisial, mengangkat isu-isu belajar; iterasi kemandirian dan kolaboasi pemecahan masalah, integrasi pengetahuan baru, penyajian solusi dan evaluasi).

\section{Persiapan Penelitian}

Setiap mengadakan penelitian perlu diadakannya persiapan penelitian agar hasil yang dicapai benar-benar optimal. Beberapa hal yang perlu dilakukan peneliti sebelum melakukan penelitian adalah sebagai berikut :

1. Melakukan observasi untuk mengidentifikasi masalah melalui wawancara dengan sesama guru mapel.

2. Peneliti meminta ijin kepada kepala sekolah untuk mengadakan penelitian.

3. Menentukan kelas yang dipilih sebagai subjek penelitian berdasarkan pertimbangan sesama guru mapel.

4. Membuat instrumen penelitian berupa rencana pembelajaran, lembar pengamatan guru, lembar pengamatan aktivitas siswa, LKS dan soal evaluasi.

5. Menyusun angket minat siswa terhadap model Problem Based Learning.

\section{Pelaksanaan Penelitian}

Penelitian ini dirancang dalam beberapa siklus, masing-masing siklus terdiri atas empat tahap yaitu perencanaan, tindakan, pengamatan dan refleksi. Dan apabila sudah mencapai hasil yang diharapkan, maka siklus dianggap cukup.

\section{Siklus I}

\section{Perencanaan}

a. Peneliti/guru merencanakan model Problem Based Learning dengan membuat rencana pembelajaran.

b. Mempersiapkan lembar kerja untuk siswa yang akan digunakan untuk menyelesaikan soal.

c. Menyiapkan lembar observasi. 
d. Lembar observasi meliputi lembar pengamatan aktivitas guru dan lembar pengamatan aktivitas siswa.

e. Peneliti/guru menyiapkan soal evaluasi. Soal evaluasi diberikan setelah menerapkan model pembelajaran.

\section{Pelaksanaan}

a. Peneliti/guru menjelaskan materi sesuai dengan rencana pembelajaran yang mengacu pada model Problem Based Learning sesuai dengan langkah-langkah dalam lembar kerja.

b. Peneliti/guru membagi siswa menjadi beberapa kelompok.

c. Peneliti/guru membagi soal kepada masing-masing kelompok.

d. Peneliti/guru membagikan lembar kerja berupa langkah-langkah dalam penyelesaikan soal evaluasi.

e. Siswa melakukan diskusi kelompok untuk menyelesaikan soal evaluasi tersebut.

Tabel 1 f. Peneliti/guru berkeliling membimbing, mengawasi dan membantu siswa yang kesulitan menyelesaikan soal evaluasi.

g. Peneliti/guru memberi motivasi kepada siswa untuk melakukan diskusi dalam kelompok untuk mencari informasi sebanyakbanyaknya dalam menyelesaikan soal yang diberikan.

h. Peneliti/guru mempersilahkan salah satu perwakilan kelompok untuk maju dan mempresentasikan hasil pekerjaannya di depan kelas.

i. Siswa yang lain memperhatikan dan boleh bertanya apabila ada yang kurang jelas.

j. Peneliti/guru melakukan evaluasi terhadap hasil pekerjaannya.

k. Peneliti/guru memberikan soal evaluasi.

\section{Pengamatan/Observasi}

Dari pengamatan yang dilakukan terhadap aktivitas siswa dalam kelompok pada siklus I diperoleh hasil sebagai berikut:

\begin{tabular}{|c|c|l|c|c|c|}
\hline \multicolumn{7}{|c|}{ TABEL KEAKTIFAN SISWA DALAM KELOMPOK SIKLUS I } \\
\hline No & \multicolumn{1}{|c|}{ Aktivitas Siswa } & Skor & $\%$ & Ket \\
\hline 1 & A. & Memperhatikan penjelasan guru & 62 & $52 \%$ & Sedang \\
\hline 2 & B. & Kerja sama dalam kelompok & 68 & $57 \%$ & Sedang \\
\hline 3 & C. & Bertanya antar siswa dan guru & 69 & $58 \%$ & Sedang \\
\hline 4 & D. & Keaktifan Menyelesaikan soal & 72 & $60 \%$ & Sedang \\
\hline 5 & E. & Kemampuan presentasi siswa & 83 & $69 \%$ & Sedang \\
\hline
\end{tabular}

Dan secara grafis dapat dilihat pada Gambar berikut:

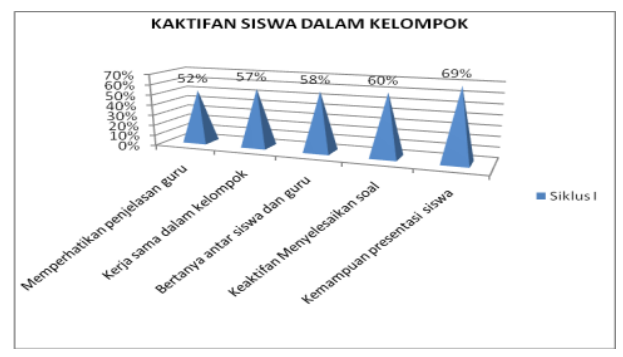

Gambar 1

Keaktifan Siswa dalam Kelompok Siklus I 
Keaktifan siswa secara individu pada siklus I dalam mengikuti kegiatan belajar mengajar dengan menggunakan model Problem Based Learning masih rendah, diperoleh skor 18 dari skor maksimal 30 dengan prosentase $60,00 \%$.

Hasil pengamatan terhadap aktivitas/performance guru pada siklus I diperoleh skor 22 atau 56,41\% dari skor maksimal 39 dengan kriteria pembelajaran "cukup" dalam menyampaikan materi, tetapi awal pelajaran kurang dapat memotivasi siswa sehingga dalam proses pembelajaran keaktifan siswa masih kurang.

Pengamatan hasil evaluasi siklus I diperoleh hasil sebagai berikut:

Tabel 2 Hasil Evaluasi Siklus I

\begin{tabular}{|c|l|c|c|}
\hline \multicolumn{4}{|c|}{ TABEL EVALUASI SIKLUS I } \\
\hline No & \multicolumn{1}{|c|}{ HasilEvaluasi } & Skor & $\%$ \\
\hline 1 & Rata-rata & 7,08 & $70,80 \%$ \\
\hline 2 & NilaiTertinggi & 8,00 & \\
\hline 3 & NilaiTerrendah & 5,20 & \\
\hline 4 & $\begin{array}{l}\text { Jumlahsiswa yang } \\
\text { tuntas }\end{array}$ & 15 & $50,00 \%$ \\
\hline 5 & $\begin{array}{l}\text { Jumlahsiswa yang } \\
\text { tidaktuntas }\end{array}$ & 15 & $50,00 \%$ \\
\hline 6 & KetuntasanKlasikal & & $50,00 \%$ \\
\hline
\end{tabular}

Karena persentase ketuntasan belajar klasikal baru mencapai 50,00\%, maka belum memenuhi hasil yang diharapkan dari indikator ketuntasn/keberhasilan.

\section{Refleksi}

Setelah melakukan pengamatan atas tindakan pembelajaran selanjutnya diadakan refleksi dari tindakan yang telah dilaksanakan.

Dalam kegiatan pada siklus I didapat hasil refleksi sebagai berikut:

a. Pada saat diskusi peneliti/guru memantau kerja masing-masing kelompok, tapi masih kurang maksimal dan bimbingan yang dilaksanakan guru terhadap kelompok masih belum merata, sehingga beberapa kelompok tidak dapat menyelesaikan soal dengan baik. Bimbingan individu juga kurang diperhatikan, sehingga ada siswa yang tidak terlibat dalam penyelesaian soal. Jika dilakukan lebih maksimal maka guru akan mengetahui karakteristik dan kelemahan siswa, sehingga siswa dapat memahami materi pembelajaran saat itu.

b. Peneliti/guru dalam menumbuhkan motivasi belajar siswa agar dapat menumbuhkan minat siswa dalam proses model Problem Based Learning masih kurang optimal.

c. Perhatian siswa terhadap penjelasan guru masih rendah.

d. Dalam mengerjakan soal siswa masih kurang aktif.

e. Pada waktu kerja kelompok siswa kurang mampu berinteraksi dengan siswa yang lain.

f. Siswa masih enggan untuk melakukan presentasi. Siswa masih saling menuding untuk melakukan presentasi di depan kelas.

g. Sikap siswa dalam memperhatikan presentasi dan pendapat teman masih kurang.

h. Ketenangan kelas dalam pembelajaran masih kurang baik atau masih banyak yang ramai sendiri.

Hasil evaluasi pada siklus I diperoleh nilai tertinggi 8,00 ; nilai terendah 5,20; nilai rata-rata 7,07; siswa yang tuntas belajar sebanyak 18 siswa atau 50,00\%; dan siswa yang tidak tuntas belajar sebanyak 18 siswa atau 50,00\%; serta diperoleh ketuntasan belajar klasikal 
$50,00 \%$. Dari hasil siklus I, berarti dalam proses belajar belum berhasil atau belum memenuhi kriteria ketuntasan belajar secara klasikal. Oleh karena itu, perlu diadakan perbaikan tindakan yang akan dilakukan pada siklus II.

\section{Siklus II}

\section{Perencanaan}

a. Berdasarkan permasalahan yang muncul dari siklus I, peneliti/guru merencanakan model Problem Based Learning pada siklus berikutnya (siklus II), dengan membuat rencana pembelajaran.

b. Menyusun lembar kerja untuk siswa. lembar kerja yang diberikan kepada siswa digunakan untuk menyelesaikan permasalahan. Menyusun lembar observasi yang akan digunakan oleh peneliti untuk mengamati aktivitas komunikasi siswa dan guru dalam pembelajaran dengan menggunakan model Problem Based Learning.

c. Menyusun soal evaluasi.

\section{Pelaksanaan}

a. Peneliti/guru menjelaskan materi sesuai dengan rencana pengajaran dan mengacu pada pembelajaran dengan menggunakan model Problem Based Learning.

b. Peneliti/guru membagi siswa menjadi beberapa kelompok. c. Peneliti/guru membagi soal kepada masing-masing kelompok.

d. Peneliti/guru membagikan lembar kerja berupa langkah-langkah dalam penyelesaikan soal: (1) (Siswa menyelesaikan masalah secara berkelompok; (2) Peneliti/guru berkeliling membimbing, mengawasi dan membantu siswa yang kesulitan menyelesaikan soal.

e. Peneliti/guru memberi motivasi kepada siswa untuk melakukan diskusi dalam kelompok untuk mencari informasi sebanyakbanyaknya dalam menyelesaikan soal yang diberikan.

f. Peneliti/guru mempersilahkan salah satu perwakilan kelompok untuk maju dan mempresentasikan hasil pekerjaannya di depan kelas.

g. Siswa yang lain memperhatikan dan boleh bertanya apabila ada yang kurang jelas.

h. Peneliti/guru melakukan evaluasi terhadap hasil pekerjaan siswa.

i. Peneliti/guru memberikan soal uji kompetensi.

\section{Pengamatan/Observasi}

a. Dari pengamatan yang dilakukan terhadap aktivitas siswa dalam siklus II yang dilakukan secara berkelompok diperoleh hasil sebagai berikut: 
Table 3

Keaktifan Siswa dalam Kelompok Siklus II

\begin{tabular}{|c|c|l|c|c|c|}
\hline \multicolumn{7}{|c|}{ TABEL KEAKTIFAN SISWA DALAM KELOMPOK SIILUS II } \\
\hline No & \multicolumn{1}{|c|}{ Aktivitas Siswa } & Skor & $\%$ & Ket \\
\hline 1 & A. & Memperhatikan penjelasan guru & 108 & $90 \%$ & Tinggi \\
\hline 2 & B. & Kerja sama dalam kelompok & 110 & $92 \%$ & Tinggi \\
\hline 3 & C. & Bertanya antar siswa dan guru & 104 & $87 \%$ & Tinggi \\
\hline 4 & D. & Keaktifan Menyelesaikan soal & 110 & $92 \%$ & Tinggi \\
\hline
\end{tabular}

Secara grafis dapat dilihat pada Gambar berikut:

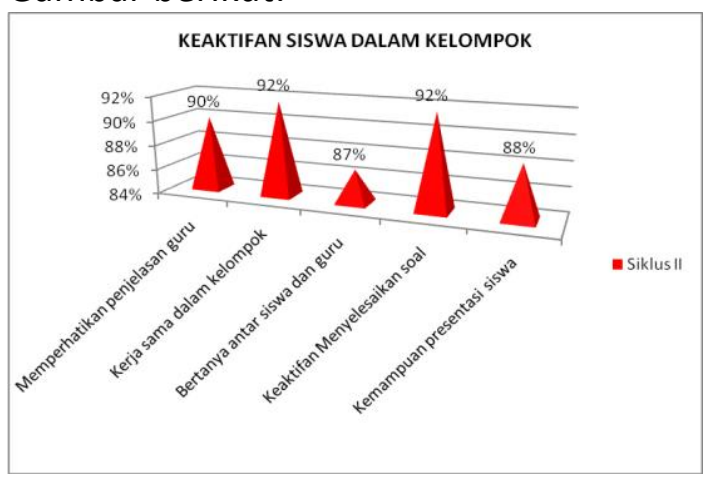

Gambar 3

Keaktifan Siswa dalam Kelompok Siklus II

b. Keaktifan siswa secara individu pada siklus II dalam mengikuti kegiatan belajar mengajar dengan menggunakan model Problem Based Learning sudah mencapai keaktifan 'tinggi', diperoleh skor 26 atau $86,67 \%$ dari skor maksimal 30.

c. Hasil pengamatan terhadap aktivitas/performance guru pada siklus II diperoleh skor 37 atau $94,87 \%$ dari skor maksimal 39 dengan kriteria "baik".

d. Pengamatan hasil uji kompetensi siklus II diperoleh hasil sebagai berikut:
Tabel 4 Hasil Evaluasi Siklus II

\begin{tabular}{|c|l|r|c|}
\hline \multicolumn{4}{|c|}{ TABEL EVALUASI SIKLUS II } \\
\hline No & \multicolumn{1}{|c|}{ HasilEvaluasi } & Skor & $\%$ \\
\hline 1 & Rata-rata & 8,68 & $86,80 \%$ \\
\hline 2 & SkorTertinggi & 10,00 & \\
\hline 3 & SkorTerrendah & 7,60 & \\
\hline 4 & $\begin{array}{l}\text { Jumlahsiswa yang } \\
\text { tuntas }\end{array}$ & 30 & $100 \%$ \\
\hline 5 & $\begin{array}{l}\text { Jumlahsiswa yang } \\
\text { tidaktuntas }\end{array}$ & 0 & $0 \%$ \\
\hline 6 & KetuntasanKlasikal & & $100 \%$ \\
\hline
\end{tabular}

Karena ketuntasan klasikal sudah mencapai $100,00 \%$ (hal ini sudah sesuai dengan kriteria yang ingin dicapai dan sudah memenuhi indikator ketuntasan belajar.

\section{Refleksi}

a. Pada saat diskusi peneliti/guru memantau kerja masing-masing kelompok, sudah maksimal dan bimbingan yang dilaksanakan guru terhadap kelompok sedah merata, sehingga beberapa kelompok dapat menyelesaikan soal dengan baik. Bimbingan individu sudah diperhatikan, sehingga seluruh siswa terlibat dalam penyelesaian masalah.

b. Peneliti/guru dalam menumbuhkan motivasi belajar siswa agar dapat menumbuhkan minat siswa dalam proses model Problem Based Learning sudah optimal. 
c. Perhatian siswa terhadap penjelasan guru sudah meningkat.

d. Dalam mengerjakan soal siswa sudah aktif.

e. Pada waktu kerja kelompok siswa sudah bisa berinteraksi dengan yang lain.

f. Siswa sudah tidak merasa malu untuk melakukan presentasi.

g. Sikap siswa dalam memperhatikan presentasi dan pendapat teman sudah membaik.

h. Ketenangan kelas dalam pembelajaran sudah baik.

i. Hasil siklus II dapat diketahui bahwa keaktifan siswa dapat dikategorikan tinggi, diperoleh skor 26 atau 86,67\% dari skor maksimal 30 dan telah memenuhi indikator keberhasilan yang telah ditetapkan.

Dan kinerja/performance guru pada Tabel 5 Perbandingan Keaktifan Siswa dalam Kelompok

\begin{tabular}{|c|l|l|c|c|c|}
\hline \multicolumn{5}{|c|}{ TABEL KEAKTIFAN SISWA DALAM KELOMPOK } \\
\hline No & & \multicolumn{1}{|c|}{ Aktivitas Siswa } & Siklus I & Siklus II & Keterangan \\
\hline 1 & A. & $\begin{array}{l}\text { Memperhatikan } \\
\text { penjelasan guru }\end{array}$ & $52 \%$ & $90,00 \%$ & Meningkat \\
\hline 2 & B. & $\begin{array}{l}\text { Kerja sama dalam } \\
\text { kelompok }\end{array}$ & $57 \%$ & $91,67 \%$ & Meningkat \\
\hline 3 & C. & $\begin{array}{l}\text { Bertanya antar siswa } \\
\text { dan guru }\end{array}$ & $58 \%$ & $86,67 \%$ & Meningkat \\
\hline 4 & D. & $\begin{array}{l}\text { Keaktifan } \\
\text { Menyelesaikan soal }\end{array}$ & $60 \%$ & $91,67 \%$ & Meningkat \\
\hline
\end{tabular}

Perbandingan secara grafis dapat dilihat pada gambar berikut: siklus II diperoleh skor 37 atau $94,87 \%$ dari skor maksimal 39, dengan kategori baik. Dari hasil evaluasi siswa pada siklus II diperoleh nilai tertinggi 10,00; nilai terendah 7,6; dan nilai rata-rata 8,67. Siswa yang tuntas belajar sebanyak 36 atau $100 \%$ dan tidak ada siswa yang tidak tuntas. Hal ini menunjukkan adanya peningkatan dibandingkan dengan siklus I, dengan demikian tidak perlu lagi siklus ke tiga.

\section{Perbandingan Siklus I dan Siklus II}

Berdasarkan uraian di atas, maka dapat dibuat tabel perbandingan siklus I dan siklus II sebagai berikut :

a. Perbandingan Keaktifan Siswa dalam Kelompok 


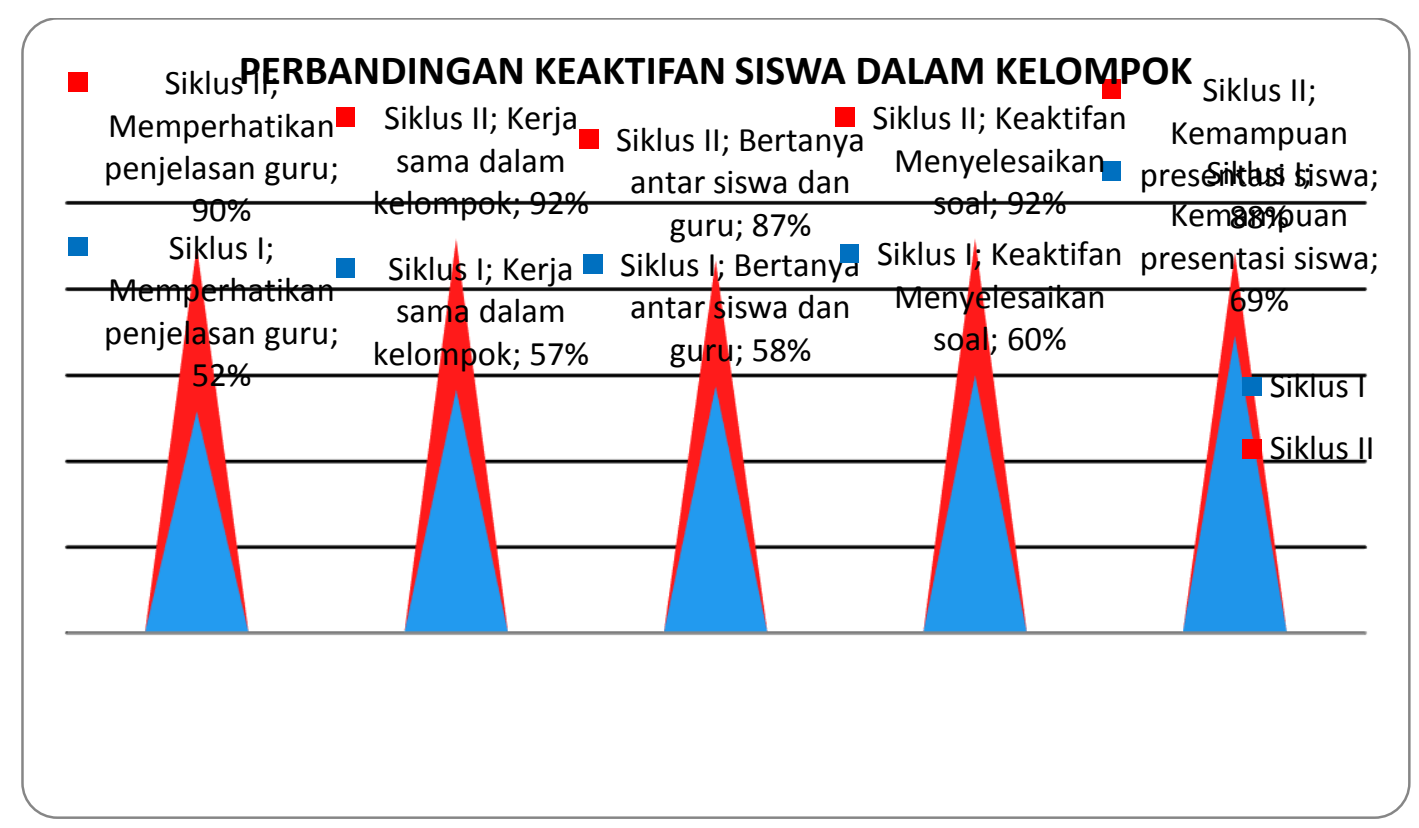

Gambar 4 Perbandingan Keaktifan Siswa dalam Kelompok

b. Perbandingan Komulatif

Tabel 6 Perbandingan Komulatif Siklus I dan Siklus II

\begin{tabular}{|c|l|c|c|}
\hline \multicolumn{4}{|c|}{ TABEL KOMULATIF PERBANDINGAN SIKLUS I DAN SIKLUS II } \\
\hline No & \multicolumn{1}{|c|}{ Indikator } & Siklus I & Siklus II \\
\hline 1 & Keaktifan siswa & $60 \%$ & $87 \%$ \\
\hline 2 & Keaktifan dalam kelompok & $59 \%$ & $90 \%$ \\
\hline 3 & Nilai rata-rata siswa & $71 \%$ & $87 \%$ \\
\hline 4 & Siswa tuntas & $50 \%$ & $100 \%$ \\
\hline 5 & Siswa tidak tuntas & $50 \%$ & $0 \%$ \\
\hline 6 & Ketuntasan klasikal & $50 \%$ & $100 \%$ \\
\hline 7 & Kinerja Guru & $56 \%$ & $95 \%$ \\
\hline 8 & Minat Siswa & \multicolumn{2}{|c|}{$82,83 \%$} \\
\hline 8 & Minat Siswa & \multicolumn{2}{|c|}{} \\
\hline
\end{tabular}

Perbandingan secara grafis dapat dilihat pada gambar berikut: 


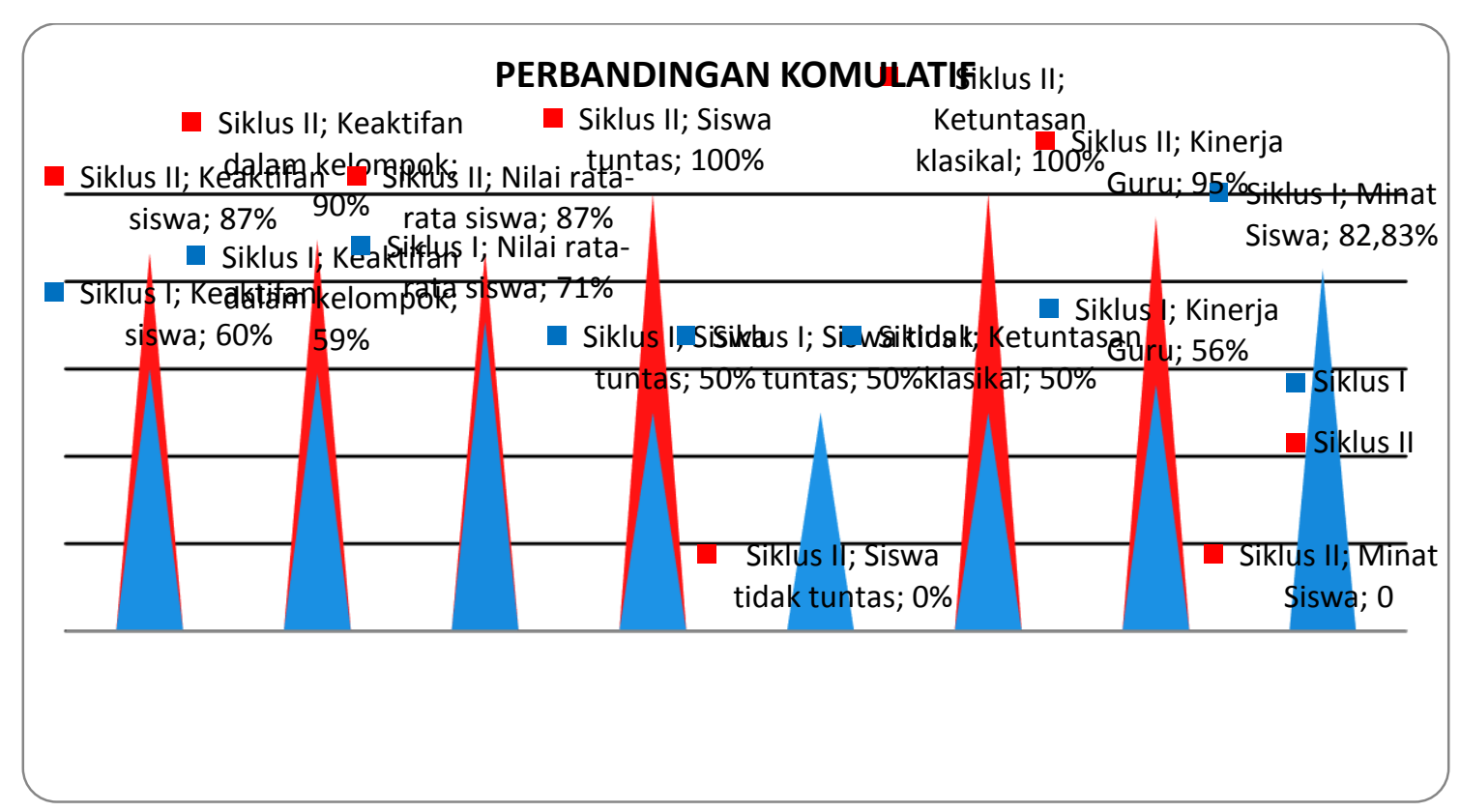

Gambar 5 Perbandingan Komulatif Siklus I dan Siklus II 


\section{Pembahasan}

Pembahasan hasil penelitian ini didasarkan pada hasil pengamatan dan dilanjutkan dengan refleksi siklus I dan siklus II. Pada siklus I berdasarkan pengamatan yang dilakukan pada guru, menunjukkan bahwa aktivitas sudah cukup baik. Dapat dilihat pada lembar hasil pengamatan aktivitas guru pada siklus I menunjukkan skor yang diperoleh yaitu 22 atau 56,41\% dari skor maksimal 39 sedang pada siklus II menunjukkan bahwa aktivitas guru sudah baik. Dapat dilihat pada lembar pengamatan aktivitas/performance guru pada siklus II, yang menunjukkan skor yang diperoleh yaitu 37 atau 94,87\% dari skor maksiaml 39, yang menunjukkan bahwa aktivitas guru mengalami peningkatan pada siklus II dibandingkan dengan siklus I.

Pengamatan kepada aktivitas siswa secara incdividu, skor yang diperoleh dari lembar pengamatan aktivitas siswa siklus I, yaitu 18 atau $60,00 \%$ dari skor maksimal 30. Hal ini menunjukkan bahwa keaktifan siswa tergolong rendah masih belum memenuhi kriteria yang diharapkan yaitu dengan prosentase minimal antara 60\%-75\%; sedang pada siklus II menunjukkan bahwa keaktifan siswa tinggi. Dapat dilihat pada lembar hasil pengamatan aktivitas siswa siklus II, yang menunjukkan skor yang diperoleh yaitu 26 atau 86,67\% dari skor maksimal 30, yang berarti sudah memenuhi kriteria yang diharapkan. Ini menunjukkan bahwa aktivitas siswa mengalami peningkatan pada siklus II dibandingkan dengan siklus I.

Hasil pengamatan terhadap diskusi dari masing-masing kelompok dalam mengerjakan lembar kerja siswa sudah dikatakan baik. Hal ini ditunjukkan dari nilai rata-rata pada siklus I mencapai 59\%; dan pada siklus II meningkat menjadi 90\%; peningkatan ini terjadi karena pada siklus II tingkat keaktifan dan kerjasama dalam kelompok lebih tinggi sehingga mereka mampu memecahkan masalah yang diberikan dengan baik.

Pengamatan pada hasil evaluasi pada siklus I dapat dilihat pada hasil evaluasi siklus I, yang menunjukkan kemampuan siswa dalam menyelesaikan soal yaitu diperoleh skor ratarata 7,08 , skor tertingg 8,00 dan skor terendah
5,2 . Siswa yang tuntas belajar sebanyak 15 siswa atau $50,00 \%$ dan yang tidak tuntas sebanyak 15 siswa atau 50,00\%. Hal ini masih belum memenuhi kriteria yang diharapkan yaitu ketuntasan belajar klasikal harus mencapai prosentase $75 \%$. Sedangkan hasil evaluasi siswa pada siklus II dapat dilihat pada hasil uji kompetensi siklus II, yang menunjukkan kemampuan siswa dalam menyelesaikan soal yaitu diperoleh skor rata-rata 8,68, skor tertingg 10,00 dan skor terendah 7,6. Siswa yang tuntas belajar sebanyak 30 siswa atau 100,00\% dan tidak ada yang tidak tuntas. Hal ini menunjukkan memenuhi kriteria yang diharapkan dan hasil belajar siswa mengalami peningkatan pada siklus II dibandingkan dengan siklus I.

Sementara hasil pengamatan terhadap antivitas siswa dalam kelompok pada siklus I mencapai $59 \%$ dan pada siklus II meningkat menjadi $90 \%$.

Hasil angket tanggapan siswa menunjukkan bahwa kebanyakan siswa menyukai model Problem Based Learning, dengan prosentase $82,92 \%$, atau kriteria "tinggi".

Jhonson and Jhonson (dalam Rusman, 2011:219) melakukan penelitiann tentang model Problem Based Learning yang hasilnya menunjukkan bahwa interaksi kooperatif memiliki berbagai pengaruh positif terhadap perkembangan anak.

Dengan demikian dapat dikatakan bahwa dalam model Problem Based Learning dapat meningkatkan prestasi belajar siswa, sehingga model pembelajaran ini dapat menjadi solusi bagi guru untuk meningkatkan prestasi belajar siswa.

\section{SIMPULAN}

Setelah dilakukan análisis data dari hasil penelitian tindakan dan pembahasan, diperoleh simpulan bahwa model problem based learning yang telah dilaksanakan pada siswa Kelas IX-F Madrasah Tsanawiyah Negeri 2 Kudus pada semester gasal tahun pelajaran 2019/2020.

Terdapat peningkatan prestasi belajar bahasa Inggris setelah diterapkan model problem based learning, hal ini ditunjukkan dari hasil evaluasi pada siklus II (meningkat) dan 
sudah sesuai dengan indikator yang telah ditetapkan, dibandingkan dengan hasil evaluasi pada siklus I. Selanjutya ada peningkatan aktivitas siswa dalam mengikuti model problem based learning, hal ini ditunjukkan aktivitas siswa pada siklus II lebih baik (meningkat) dibandingkan dengan aktivitas siswa pada siklus I.

Terdapat peningkatan kinerja/performance guru dalam pelaksanaan model problem based learning. Hal ini ditunjukkan dengan adanya peningkatan kinerja/performance guru pada siklus II lebih baik dibanding siklus I. Respon siswa terhadap pelaksanaan model problem based learning, menunjukkan respon yang sangat baik.

Berdasarkan hasil penelitian tindakan pada siswa kelas IX-F Madrasah Tsanawiyah Negeri 2 Kudus pada semester gasal tahun pelajaran 2019/2020 peneliti memberikan saran: (1) Dalam pembelajaran perlu adanya pendekatan dan strategi yang sesuai dengan materi dan kondisi siswa; (2) Model problem based learning sebaiknya diterapkan oleh guru, karena dengan adanya pembelajaran ini dapat meningkatkan kreativitas dan keaktivan siswa, dapat menjadikan siswa termotivasi untuk giat belajar, serta dapat meningkatkan prestasi belajar siswa; (3) Dalam model problem based learning, guru sebagai fasilitator hendaknya mendorong siswa agar lebih aktif dan termotivasi dalam pembelajaran; (4) Guru hendaknya lebih sabar dan kooperatif dalam pembelajaran, khususnya dalam menghadapi siswa yang kurang dan sulit menerima pelajaran, serta guru harus pandai-pandai mengelola kelas.

\section{DAFTAR PUSTAKA}

Atas, D. P. (2017). Model-Model Pembelajaran. Jakarta: Direktorat Jenderal Pendidikan Dasar dan Menengah Kementerian Pendidikan dan Kebudayaan.

Birch, W. (1986). Towards a Model for Problembased Learning. Studies in Higher Education, 11(1), 73-82. https://doi.org/10.1080/03075078612331 378471

Depdiknas. (2017). Model-Model Pembelajaran. Jakarta: Direktorat Pembinaan Sekolah
Menengah Atas, Direktorat Jenderal Pendidikan Dasar dan Menengah Kementerian Pendidikan dan Kebudayaan.

Diyas Puspandari, S. S. M. P. (2010). Model Dan Desain Penelitian Tindakan Kelas Untuk Pembelajaran Keterampilan Berbicara. Seminar Dan Lokakarya Nasional Penelitian Tindakan Kelas Dalam Perspektif Etnografi. Program Magister Liguistik Undip, 2 Oktober 2010, 91-107.

Fogarty, R. (1997). Problem-based learning and other curriculum models for the multiple intelligences classroom. Illionis: Sky Light Gorghiu, G., Drăghicescu, L. M., Cristea, S., Petrescu, A.-M., \& Gorghiu, L. M. (2015). Problem-based Learning - An Efficient Learning Strategy in the Science Lessons Context. Procedia - Social and Behavioral Sciences, 191, 1865-1870. https://doi.org/10.1016/j.sbspro.2015.04. 570

Hikmat, A., \& Solihati, N. (2013). Bahasa Indonesia. . Jakarta: Grasindo.

Hintz, M. M. C. (2005). Can problem-based learning address content and process? Biochemistry and Molecular Biology Education, 33(5), 363-368. https://doi.org/10.1002/bmb.2005.49403 305363

Howey, K. R. (2001). Contetextual Teaching And Learning Teaching For Andistending Through Integration Of Academic And Teahing Education. Forum, 16(2).

Ibrahim, M., \& M, N. (2000). Pembelajaran Berdasarkan Masalah. Surabaya : UNESA - University Press.

Karnisius, Hikmat, A., \& Sholihat, N. (2013). Bahasa Indonesia untuk Mahasiswa S1 \& Pascasarjana, Guru, Dosen, Praktisi, dan Umum. Jakarta: PT Grasindo Khasinah, S. (2013). Classroom Action Research. Jurnal Pionir, Volume 1, Nomor 1, 1(2), 33-61. https://doi.org/10.17977/um013v1i42017 p156

Krishnan, S., Gabb, R., \& Vale, C. (2011). Problem-Based Learning. Australasian Journal of Engineering Education, 17(2), 67-78. 
https://doi.org/10.1080/22054952.2011.1 1464057

Major, T., \& Mulvihill, T. M. (2018). Problembased learning pedagogies in teacher education: The case of Botswana. Interdisciplinary Journal of Problem-Based Learning, 12(1). https://doi.org/10.7771/1541-5015.1543

Miles, M. B., \& Huberman, A. M. (1994). Qualitative Data Analysis. In R. Holland (Ed.), SAGE Publication (2nd ed., Vol. 251, Issue 2). SAGE Publication Ltd. https://doi.org/10.1007/BF02759913

Nuh, M. (2014). Permendikbud Tahun 2014. 14.

Pupuh, F. (2018). Pendekatan Metode, dan Teknik dalam Pembelajaran Bahasa. 2(1), 12.

Rosidah, C. T. (2018). Penerapan Model Problem Based Learning Untuk Menumbuhkembangkan Higher Order Thinking Skill Siswa Sekolah Dasar. Inventa, 2(1), 62-71. https://doi.org/10.36456/inventa.2.1.a162 7

Sugiyono. (2017). Metode Penelitian Kuantitatif, Kualitatif, dan R\&D. Bandung: CV. Alfabeta.

Tan, O.-S. (2003 ). Problem Based Learning Innovation: Using Problem to. Power Learning in 21st Century. Singapore: Thompson.

Watson, D. E. (1996). Using problem-based learning to improve educational outcomes. Occupational Therapy International, 3(2), 81-93. https://doi.org/10.1002/oti.29

Yin, R. K. (2016). Qualitative Research: from Start to Finish (2nd ed.). The Guilford Press. 